DOI: $10.19195 / 0137-1134.114 .27$

\author{
RAFAŁ BLICHARZ \\ Uniwersytet Śląski \\ rafal.blicharz@us.edu.pl
}

\title{
KILKA UWAG NA TEMAT PRZEPISÓW OGÓLNYCH PROJEKTU USTAWY PRAWO PRZEDSIĘBIORCÓW
}

\begin{abstract}
Abstrakt: Tak zwana Konstytucja dla biznesu, obejmująca cztery odrębne ustawy, wprowadza kilka nowych rozwiązań w stosunku do ustawy o swobodzie działalności gospodarczej. Uwidaczniają się one między innymi w przepisach ogólnych ustawy Prawo przedsiębiorców. Do nowych rozwiązań należy chociażby tak zwana nieewidencjonowana działalność gospodarcza, dotycząca działalności prowadzonej przez osoby fizyczne na mniejszą skalę.
\end{abstract}

Słowa kluczowe: Konstytucja dla biznesu, Prawo przedsiębiorców, działalność gospodarcza, nieewidencjonowana działalność gospodarcza

Opracowywana w tym samym czasie, w którym autor pisał niniejszy artykuł, a prawdopodobnie już obowiązująca w dniu jego publikacji tak zwana Konstytucja dla biznesu (dotychczasowa jednoustawowa regulacja została rozbita na cztery odrębne ustawyl, których zasady wejścia w życie określa odrębna ustawa wprowadzająca) zakłada kilka nowych rozwiązań w stosunku do ustawy o swobodzie działalności gospodarczej ${ }^{2}$. Jednym z nich jest „,nieewidencjonowana działalność gospodarcza", dotycząca działalności gospodarczej prowadzonej na mniejszą skalę. Rozwiązanie to poniekąd nawiązuje do art. 2 historycznej już ustawy o działalności gospodarczej z $1988 \mathrm{roku}^{3}$. Obowiązujące wówczas prawo przewidywało „uboczną działalność zarobkową" polegającą na osobistym prowadzeniu działalności gospodarczej przez osoby fizyczne, z której zarobek stanowił dodatkowe źródło dochodu. Ponadto przedmiot takiej działalności musiał mieścić się w za-

1 Ustawa Prawo przedsiębiorców, ustawa o Rzeczniku Małych i Średnich Przedsiębiorców, ustawa o zasadach uczestnictwa przedsiębiorców zagranicznych i innych osób zagranicznych w obrocie gospodarczym na terytorium Rzeczypospolitej Polskiej oraz ustawa o Centralnej Ewidencji i Informacji Działalności Gospodarczej i Punkcie Informacji dla Przedsiębiorcy.

2 Ustawa z dnia 2 lipca 2004 r. (tekst jedn. Dz.U. z 2017 r. poz. 2168).

3 Ustawa z dnia 23 grudnia 1988 r. (Dz.U. z 1988 r. Nr 41, poz. 324 z póź. zm.). 
kresie określonym ustawą ${ }^{4}$. Osoba prowadząca uboczną działalność zarobkową była zwolniona z obowiązku jej rejestracji.

Tymczasem, zgodnie z art. 5 projektowanej ustawy Prawo przedsiębiorców, nie stanowi działalności gospodarczej działalność wykonywana przez osobę fizyczną, której przychód należny z tej działalności nie przekracza w żadnym miesiącu 50\% kwoty minimalnego wynagrodzenia, w myśl ustawy z dnia 10 października 2002 roku o minimalnym wynagrodzeniu za pracę (Dz.U. z 2017 r. poz. 847), i która w okresie ostatnich 60 miesięcy nie wykonywała działalności gospodarczej. Projekt ustawy Prawo przedsiębiorców, w przeciwieństwie do ustawy o działalności gospodarczej z 1988 roku, nie uznaje za działalność gospodarczą działalności opisanej w art. 5. Aby przyjąć, że dana działalność jest działalnością nieewidencjonowaną, muszą być zatem spełnione trzy przesłanki. Pierwsza: ma ona charakter podmiotowy. Działalność nieewidencjonowaną może bowiem prowadzić tylko osoba fizyczna. Druga przesłanka - przychodowa — odnosi się do wielkości przychodu, jaki ta działalność przynosi. Natomiast trzecia ma charakter negatywny i stanowi wymóg uprzedniego nieprowadzenia działalności gospodarczej przez okres 60 miesięcy. Ustawa zastrzega również, że działalności nieewidencjonowanej nie stosuje się do działalności wykonywanej w ramach umowy spółki cywilnej. Jest to logicznie uzasadnione, skoro działalność nieewidencjonowana została zastrzeżona dla działalności prowadzonej raczej w niewielkim wymiarze. Prowadzenie takiej działalności przez wspólników spółki cywilnej, którzy są odrębnymi przedsiębiorcami, skutkowałoby ominięciem tego ograniczenia.

Równocześnie kwalifikacja określonej działalności jako nieewidencjonowanej pociąga za sobą konsekwencje. Ponieważ działalność nieewidencjonowana nie jest działalnością gospodarczą, osoba ją wykonująca nie jest przedsiębiorcą w rozumieniu projektu ustawy Prawo przedsiębiorców. Ma ona jednak wybór. Według swojego uznania może, ale nie musi, zarejestrować (zaewidencjonować) wykonywaną działalność nieewidencjonowaną. Jeśli zdecyduje się ją zgłosić do Centralnej Ewidencji i Informacji o Działalności Gospodarczej (CEIDG), działalność ta uzyska status działalności gospodarczej z dniem wskazanym we wniosku o wpis, a osoba ją wykonująca stanie się przedsiębiorcą.

Intencją ustawodawcy przy wprowadzaniu działalności nieewidencjonowanej było odformalizowanie drobnej działalności gospodarczej prowadzonej przez

4 „1) a) wytwarzanie przedmiotów użytku osobistego, domowego i gospodarskiego oraz rękodzieła ludowego i artystycznego, b) naprawy i konserwacje przedmiotów użytku osobistego, domowego i gospodarskiego oraz mieszkań, a także wykonywanie innych usług z użyciem materiałów i narzędzi własnych lub powierzonych, z wyjątkiem zarobkowego przewozu osób, c) czynności handlowe polegające na sprzedaży nieprzetworzonych produktów rolnych, ogrodniczych, sadowniczych, hodowlanych, w tym mięsa z uboju gospodarczego, runa leśnego, owoców leśnych, posiłków domowych, a także przedmiotów określonych w lit. a); 2) podejmujące działalność wytwórczą w rolnictwie w zakresie produkcji roślinnej i zwierzęcej, ogrodnictwa oraz sadownictwa”, art. 2 ust. 4 ustawy. 
osoby fizyczne 5 . Choć nie można wykluczyć, że taką drobną działalność gospodarczą mogłyby prowadzić także inne osoby, ustawodawca jednak expressis verbis wyłączył taką możliwość. Poniekąd wynika stąd również druga przesłanka - kryterium przychodowe. Wskazany przychód należny z tej działalności nie może przekroczyć w żadnym miesiącu 50\% kwoty minimalnego wynagrodzenia, o którym mowa w ustawie o minimalnym wynagrodzeniu za pracę. W 2018 roku minimalne wynagrodzenie za pracę ustalone zostało w wysokości $2100 \mathrm{zł}$. Tak określona kwota przychodu należnego dopuszczalnego z działalności nieewidencjonowanej (50\% z 2100 zł) powoduje, że co do zasady prowadzenie jej przez inne osoby niż osoby fizyczne z ekonomicznego punktu widzenia jest nieopłacalne. Ponadto, jak się wydaje, nawet dla osób fizycznych działalność nieewidencjonowana zwykle będzie jedynie dodatkowym źródłem przychodów. Podkreślenia przy tym wymaga, że jeżeli przychód należny z działalności nieewidencjonowanej przekroczył w danym miesiącu górną granicę przychodów, o których mowa w projekcie ustawy, działalność ta jest uznawana za działalność gospodarczą, począwszy od dnia, w którym nastąpiło przekroczenie. W takiej sytuacji działalność taka traci status nieewidencjonowanej, a osoba ją prowadząca ma obowiązek złożyć wniosek o wpis do CEIDG w terminie 7 dni od dnia, w którym nastąpiło przekroczenie. Ustawodawca dopuszcza jedynie siedmiodniowy termin na istnienie rozbieżności między stanem faktycznym a ewidencyjnym. W związku z tym należy przyjąć, że osoba dokonująca rejestracji powinna we wniosku określić jako termin rozpoczęcia działalności dzień złożenia wniosku.

Tak relatywnie nisko określona kwota przychodów warunkująca niepowstanie wymogu zgłoszenia działalności do ewidencji działalności gospodarczej niesie także dalej idące konsekwencje. Dotychczas osiąganie przychodów niejednokrotnie przewyższających kwotę $50 \%$ minimalnego wynagrodzenia nie było traktowane jak wykonywanie działalności gospodarczej, o ile nie były spełnione pozostałe przesłanki wynikające z definicji działalności gospodarczej. Żaden przepis nie uzależniał bowiem wykonywania działalności gospodarczej od wysokości osiąganych przychodów. Biorąc pod uwagę, że wiele osób prowadzi niezarejestrowaną działalność, której zakwalifikowanie jako działalności gospodarczej może być kontrowersyjne, i osiąga przy tym przychody przekraczające 1050 zł miesięcznie, można przypuszczać, że wejście w życie ustawy Prawo przedsiębiorców spowoduje istotny wzrost liczby przedsiębiorców. Kluczowe dla osób prowadzących działalność nieewidencjonowaną chcących zachować status nieprzedsiębiorcy będzie zatem utrzymanie przychodów z tej działalności na poziomie nie wyższym niż $50 \%$ minimalnego wynagrodzenia.

5 Zob. uzasadnienie do projektu ustawy Prawo przedsiębiorców, druk sejmowy nr $2051 \mathrm{z}$ dnia 21 listopada 2017 r., s. 58-59. Z tych też powodów nie można uznać za działalność nieewidencjonowaną działalności reglamentowanej (art. 44 ust. 3 projektu ustawy Prawo przedsiębiorców). 
Trzecią przesłanką uznania działalności gospodarczej za nieewidencjonowaną jest jej niewykonywanie przez ostatnie 5 lat. Ustawodawca nie określa jednak przedmiotu działalności, której nie można prowadzić we wskazanym okresie. Chodzi zatem o niewykonywanie działalności gospodarczej w ogóle, a nie w tym samym przedmiocie, który będzie wykonywany jako działalność nieewidencjonowana. Jak się wydaje, należy również przyjąć, że przesłanka ta obejmuje także niewykonywanie działalności gospodarczej niezarejestrowanej. Jeśli osoba fizyczna wykonywała działalność gospodarczą w okresie do 60 miesięcy wstecz, ale jej nie zgłosiła do CEIDG, to jej działalność po wejściu w życie projektu ustawy Prawo przedsiębiorców nie będzie mogła zostać uznana za działalność nieewidencjonowaną. Wynika to bezpośrednio z art. 5 ust. 1 projektu ustawy Prawo przedsiębiorców, który nie wiąże trzeciej przesłanki z wpisem do CEIDG, lecz z wykonywaniem działalności.

Rozwiązanie to koresponduje z podziałem przedsiębiorców na formalnych i materialnych. Przedsiębiorcą w znaczeniu formalnym jest podmiot wpisany do rejestru (ewidencji), na przykład spółka akcyjna, natomiast w znaczeniu materialnym — podmiot, który w świetle określonego aktu prawnego, niezależnie od tego, czy jest wpisany do rejestru lub ewidencji, może być uznany za przedsiębiorcę, gdyż wykonuje działalność wyczerpującą przesłanki uznania jej za działalność gospodarczą. Kryterium podziału ma charakter formalny i jest nim wpis lub jego brak do właściwego rejestru (ewidencji). Kryterium takim może być również sam fakt prowadzenia działalności gospodarczej. Wówczas przedsiębiorcą w znaczeniu materialnym jest podmiot, który (realnie) prowadzi działalność gospodarczą, natomiast $\mathrm{w}$ znaczeniu formalnym — podmiot, który nie wykonuje działalności gospodarczej, jednak może być uznany za przedsiębiorcę, gdyż dopełnił obowiązku rejestracyjnego ${ }^{6}$. Należy przy tym zauważyć, że wbrew zaprezentowanemu stanowisku co do zasady trudno będzie jednak organowi ewidencyjnemu udowodnić osobie fizycznej, że w okresie ostatnich 60 miesięcy była przedsiębiorcą w rozumieniu materialnym. W praktyce zatem działalność takich osób będzie mogła zostać uznana za nieewidencyjną.

Projektodawca ustawy Prawo przedsiębiorców nie wyjaśnia, dlaczego wprowadzono okres karencji i dlaczego wynosi on 60 miesięcy. Trudno więc znaleźć uzasadnienie teleologiczne trzeciej przesłanki. Jeśli wolą prawodawcy było zwolnienie z obowiązków ciążących na przedsiębiorcach osób wykonujących działalność gospodarczą na małą skalę, wprowadzenie limitu czasowego wydaje się zbędnym ograniczeniem skorzystania z takiej możliwości. Rozwiązanie to może prowadzić do nierównego traktowania przedsiębiorców. Jeśli bowiem dana osoba we wskazanym okresie 60 miesięcy wykonywała zarejestrowaną działalność gospodarczą, ale prowadziła ją na porównywalnie lub równie małą skalę, jak jest

6 Zob. R. Blicharz, M. Pawełczyk, Przedsiębiorca, czyli kto?, „Przegląd Ustawodawstwa Gospodarczego" (dalej: PUG) 2004, nr 3. 
to wymagane przy działalności nieewidencjonowanej, nie będzie mogła skorzystać z dobrodziejstw, jakie daje działalność nieewidencjonowana. W podobnej sytuacji znajdą się osoby, które były zarejestrowane, ale nie podjęły działalności lub ją zawiesiły. Wyjaśnienie braku możliwości prowadzenia przez takie osoby działalności nieewidencjonowanej może okazać się kłopotliwe.

Zagadnieniem budzącym wątpliwości może być również charakter prawny działalności objętej regulacją działalności nieewidencjonowanej. Działalność nieewidencjonowana z pewnością dotyczy działalności gospodarczej. Jeśli więc osoba fizyczna prowadzi zorganizowaną działalność zarobkową we własnym imieniu i w sposób ciągły (art. 3 projektu ustawy Prawo przedsiębiorców definiujący działalność gospodarczą), a przy tym jej przychody nie przekraczają 50\% minimalnego wynagrodzenia, to może, ale nie musi, zgłosić do CEIDG tak wykonywaną działalność. Problem jednak może pojawić się w wypadku osoby, która nie prowadzi działalności gospodarczej, ale która osiągnęła przychód powyżej 50\% minimalnego wynagrodzenia choćby tylko w jednym miesiącu. Jego źródłem może być literalna wykładnia art. 5 projektowanej ustawy Prawo przedsiębiorców, która przy nieodpowiedniej interpretacji odnosi działalność nieewidencjonowaną nie tyle do działalności gospodarczej, ile do działalności w ogóle. Zgodnie z art. 5 projektu nie stanowi działalności gospodarczej działalność wykonywana przez osobę fizyczną, której przychód należny z tej działalności nie przekracza w żadnym miesiącu 50\% kwoty minimalnego wynagrodzenia. Określenie „nie stanowi działalności gospodarczej działalność wykonywana przez osobę fizyczną" nie ogranicza regulacji art. 5 tylko do działalności gospodarczej, ale odnosi się do każdej działalności wykonywanej przez osobę fizyczną, także działalności niebędącej działalnością gospodarczą. Dodatkowym argumentem przemawiającym za takim rozumieniem działalności nieewidencjonowanej jest ust. 3 art. 5 projektu ustawy Prawo przedsiębiorców — zgodnie z nim działalnością gospodarczą staje się każda działalność, o której mowa w ust. 1, z której przychód należny przekroczył próg 50\% minimalnego wynagrodzenia. Ustawa nie wymaga przy tym, aby działalność ta była działalnością gospodarczą. Wystarczy tylko przekroczenie wskazanego progu przychodów.

Przyjęcie takiej wykładni art. 5 projektu Prawa przedsiębiorców prowadzi jednak do daleko idących i — co należy podkreślić — błędnych konsekwencji. Przede wszystkim oznaczałoby to, że art. 5 projektu zawiera poniekąd ukrytą (bo niewynikającą expressis verbis z przepisu) autonomiczną definicję działalności gospodarczej, w której świetle za taką należy uznać każdą działalność osób fizycznych, nawet niebędącą działalnością gospodarczą, z której osiągną one choć w jednym miesiącu przychód należny powyżej 50\% minimalnego wynagrodzenia. Kolejnym skutkiem takiego rozumowania byłby obowiązek zgłaszania się do Centralnej Ewidencji i Informacji Działalności Gospodarczej osób fizycznych, które nie prowadzą działalności gospodarczej w rozumieniu art. 3 projektu Prawa przedsiębiorców, lecz osiągają wskazany przychód. Kluczem do uznania, czy 
dana osoba, której przychód należny choćby w jednym miesiącu przekroczył 50\% minimalnego wynagrodzenia, jest przedsiębiorcą, jest ustalenie, czy wykonywana przez nią działalność jest działalnością gospodarczą. Jeśli prowadzona przez nią działalność nie jest działalnością gospodarczą, nawet przekroczenie określonego projektem Prawa przedsiębiorców progu przychodu należnego nie może spowodować obowiązku rejestracji w CEIDG. W przeciwnym wypadku w CEIDG zarejestrowani byliby przedsiębiorcy prowadzący działalność gospodarczą w rozumieniu art. 3 projektu ustawy Prawo przedsiębiorców oraz przedsiębiorcy prowadzący działalność gospodarczą w rozumieniu art. 5 projektu tej ustawy. Podkreślenia wymaga, że niezależnie od uznania danej osoby fizycznej za przedsiębiorcę w świetle przepisów projektowanej ustawy osoba ta może mieć status przedsiębiorcy na gruncie prawa prywatnego - kodeksu cywilnego ${ }^{7}$.

Oprócz działalności nieewidencjonowanej ustawodawca wprowadził do projektu ustawy Prawo przedsiębiorcy także wiele nowych zasad. Część z nich już obowiązywała, choć nie były wymienione expressis verbis, jedynie wynikały $\mathrm{z}$ innych przepisów prawa, w tym Konstytucji $\mathrm{RP}^{8}$ oraz bogatego orzecznictwa Trybunału Konstytucyjnego. Prawodawca postanowił jednak te zasady powtórzyć lub bezpośrednio wyrazić dla przejrzystości regulacji oraz podkreślenia ich wagi, $\mathrm{w}$ tym dotarcia $\mathrm{z}$ ich znajomością do przedsiębiorców, dla których nie zawsze były oczywiste (walor edukacyjny) ${ }^{9}$. Jak się wydaje, przynajmniej równie ważnym adresatem tych norm są organy administracji publicznej załatwiające sprawy przedsiębiorców ${ }^{10}$.

Przykładem może tu być rzekomo poszerzona zasada legalizmu (jak przyjęto w uzasadnieniu do projektu — zasada ,co nie jest prawem zabronione, jest dozwolone") ${ }^{11}$, zgodnie z którą przedsiębiorca może podejmować wszelkie działania z wyjątkiem tych, których zakazują przepisy prawa, a zobowiązanie go do określonego zachowania może nastąpić tylko na podstawie przepisów prawa (art. 8 projektu ustawy Prawo przedsiębiorców). Zasada ta przystaje do wolności człowieka zagwarantowanej art. 30-31 Konstytucji RP czy zasady swobody zawierania umów (art. $353^{1}$ k.c.), i nie wnosi niczego nowego do zakresu praw przedsiębiorców. Pod rządami ustawy o swobodzie działalności gospodarczej przedsiębiorcy również mieli prawo podejmowania wszelkich działań, które nie były sprzeczne z prawem. Podobnie rzecz się ma w odniesieniu do możliwości nakładania na przedsiębiorców obowiązków. I tu art. 22 Konstytucji RP jednoznacznie przesądza, że ograniczenie wolności działalności gospodarczej jest dopuszczalne tylko

7 Ustawa z dnia 23 kwietnia 1964 r. (tekst jedn. Dz.U. z 2017 r. poz.459 z póź. zm.; dalej: k.c.).

8 Konstytucja Rzeczypospolitej Polskiej (Dz.U. z 1997 r. Nr 78, poz. 483 z póź. zm.).

9 Zob. s. 65 uzasadnienia do projektu ustawy Prawo przedsiębiorców.

10 Tak też przyjmuje projektodawca; zob. s. 65 n. uzasadnienia do projektu ustawy Prawo przedsiębiorców.

11 Zob. ibidem. 
w drodze ustawy i - co więcej — jedynie ze względu na ważny interes publiczny ${ }^{12}$.

Pewnym novum jest natomiast zasada domniemania uczciwości przedsiębiorców. Nakłada ona na organ administracyjny obowiązek kierowania się zaufaniem do przedsiębiorcy, zakładania, że działa on zgodnie z prawem, uczciwie oraz z poszanowaniem dobrych obyczajów ${ }^{13}$. Zasadę tę można jednak również wyprowadzić z zasady praworządności oraz demokratycznego państwa prawnego $^{14}$. Jej źródła można także dostrzec $\mathrm{w}$ art. 7-8 kodeksu postępowania administracyjnego ${ }^{15}$, które nie tylko zobowiązują organy administracji publicznej do dochodzenia prawdy obiektywnej w toku postępowania administracyjnego, lecz także za zasadę $\mathrm{w}$ ich działalności przyjmują pogłębianie zaufania obywateli do organów państwa ${ }^{16}$.

Niewątpliwie nowe rozwiązanie wprowadza art. 10 ust. 2 projektu ustawy Prawo przedsiębiorców. Przewiduje on zasadę rozstrzygania wątpliwości co do faktów na korzyść przedsiębiorcy. Zgodnie z nim, jeżeli przedmiotem postępowania przed organem jest nałożenie na przedsiębiorcę obowiązku bądź ograniczenie lub odebranie uprawnienia, a w tym zakresie pozostają niedające się usunąć wątpliwości co do stanu faktycznego, organ zobowiązany jest rozstrzygnąć wątpliwości na korzyść przedsiębiorcy. Trzeba podkreślić, że zasada ta znajduje zastosowanie tylko w postępowaniach, w wyniku których na przedsiębiorcę mogą zostać nałożone obowiązki bądź może zostać mu ograniczone lub odebrane uprawnienie (na przykład nałożenie kary pieniężnej, ograniczenie zakresu koncesji). W innych sprawach zasada ta nie może znaleźć zastosowania (między innymi w postępowaniach, których przedmiotem jest wydanie zezwolenia czy koncesji). Ponadto zasady tej nie stosuje się, jeżeli w postępowaniu uczestniczą podmioty o spornych interesach lub wynik postępowania ma bezpośredni wpływ na interesy osób trzecich; gdy odrębne przepisy wymagają od przedsiębiorcy wykazania określonych faktów

12 K. Kiczka, Jakość publicznego prawa gospodarczego w świetle orzecznictwa Trybunału Konstytucyjnego, [w:] Kryzys prawa administracyjnego?, t. 1. Jakość prawa administracyjnego, red. D.R. Kijowski, A. Miruć, A. Suławko-Karetko, Warszawa 2012, s. 389-414.

13 Na ten temat zob. J. Łętowski, Glosa do wyroku NSA z dnia 11 czerwca 1981 r., SA 820/81, OSPiKA 1982, z. 1-2, poz. 22.

14 Por. M. Derlatka et al., [w:] Konstytucja Rzeczypospolitej Polskiej, t. 1, red. L. Garlicki, M. Zubik, Warszawa 2016, komentarz do art. 2 i 7, s. 94-173, 239-257; R. Balicki et al., [w:] Konstytucja Rzeczypospolitej Polskiej. Komentarz, red. M. Haczkowska, Warszawa 2014, komentarz do art. 2 i 7, s. 15-16, 20.

15 Ustawa z dnia 14 czerwca 1960 r. (tekst jedn. Dz.U. z 2017 r. poz. 1257 z póź. zm.; dalej: k.p.a.).

16 Zob. P. Przybysz, Kodeks postępowania administracyjnego. Komentarz, Warszawa 2013, s. 52-63; G. Łaszczyca, C. Martysz, A. Matan, Kodeks postępowania administracyjnego. Komentarz, t. 1. Komentarz do art. 1-103, Warszawa 2010, s. 110-129. Zob. też wyrok WSA w Warszawie z dnia 12 września 2008 r., V SA/Wa 943/08, LEX nr 470086; wyrok WSA w Warszawie z dnia 3 marca 2008 r., IV SA/Wa 62/08, LEX nr 480497; wyrok NSA z dnia 21 kwietnia 1994 r., SA/Po 3423/93, niepubl. 
oraz gdy wymaga tego ważny interes publiczny, w tym istotne interesy państwa, a w szczególności jego bezpieczeństwo, obronność lub porządek publiczny. Zasada rozstrzygania wątpliwości co do faktów na korzyść przedsiębiorcy znajduje zastosowanie jako środek ostateczny, to jest gdy udowodnienie określonych okoliczności przez organ administracyjny lub samego przedsiębiorcę nie jest możliwe, co powoduje niedające się usunąć wątpliwości. Podkreślenia przy tym wymaga, że obowiązek ustalenia stanu faktycznego w sprawach objętych zakresem zastosowania tej zasady spoczywać będzie zarówno na organie administracyjnym, jak i przedsiębiorcy. Wynika to bezpośrednio z art. 7 k.p.a. w zw. z art. 77 i 80 k.p.a. (zasady prawdy obiektywnej), zgodnie z którym w toku postępowania organy administracji publicznej stoją na straży praworządności, z urzędu lub na wniosek stron podejmujące wszelkie czynności niezbędne do dokładnego wyjaśnienia stanu faktycznego oraz do załatwienia sprawy, mając na względzie interes społeczny i słuszny interes stron ${ }^{17}$.

W ślad za zaprezentowaną zasadą prawodawca przyjął także zasadę in dubio pro libertate, oznaczającą rozstrzyganie wątpliwości co do treści normy prawnej na korzyść przedsiębiorcy (art. 11 projektu ustawy Prawo przedsiębiorców). Konstrukcja tej zasady opiera się na zasadzie rozstrzygania wątpliwości co do faktów na korzyść przedsiębiorcy. Znajduje więc zastosowanie jedynie w postępowaniach, których przedmiotem jest nałożenie na przedsiębiorcę obowiązku bądź ograniczenie lub odebranie przysługującego mu uprawnienia i nie znajduje zastosowania, gdy sprzeciwiają się temu sporne interesy stron albo interesy osób trzecich, na które wynik postępowania ma bezpośredni wpływ, a ponadto gdy wymaga tego ważny interes publiczny ${ }^{18}$.

Kluczowym elementem konstrukcyjnym obu zasad, zarówno dotyczącej rozstrzygania wątpliwości co do faktów, jak i dotyczącej rozstrzygania wątpliwości co do treści normy prawnej, jest sam fakt istnienia wątpliwości. Jak się wydaje, oś sporu dotyczyć będzie tego, czy w okolicznościach danego wypadku istnieją wątpliwości, czy też ich nie ma. Mając na względzie przedmiot postępowania, organ administracyjny zwykle nie będzie dostrzegał wątpliwości, w przeciwieństwie do strony — przedsiębiorcy. Szczególne trudności mogą pojawić się przy interpretacji terminów o nieostrym zakresie znaczeniowym. Celem przepisów, które posługują się takimi nieostrymi sformułowaniami, nie jest wywoływanie wątpliwości interpretacyjnych, ale stworzenie pewnego luzu interpretacyjnego pozwalającego elastycznie stosować określoną normę ${ }^{19}$. Analogiczne problemy

17 Zob. wyrok NSA z dnia 17 maja 1994 r., SA/Lu 1921/93, LEX nr 26517; wyrok NSA z dnia 4 czerwca 1998 r., I SA/Kr 1052/97, LEX nr 33618; wyrok NSA z dnia 25 czerwca 1999 r., I SA 1551/98, LEX nr 48556; wyrok NSA z dnia 4 grudnia 1996 r., SA/Łd 2620/95, LEX nr 27407.

18 Stanowi ona również powtórzenie art. 7a k.p.a.

19 M. Jaśkowska, Uznanie administracyjne, Torun 1983; eadem, Zwiąanie decyzji administracyjnej ustawa, Toruń 1998; M. Mincer, Uznanie administracyjne, Toruń 1983, s. 64 n.; J. Starościak, Swobodne uznanie $w$ teorii prawa administracyjnego, Warszawa 1948; idem, Swobodne uznanie 
mogą powstawać przy rozbieżnościach, jakie zachodzą w wypadku zastosowania różnych wykładni danego przepisu ${ }^{20}$.

Niezależnie od tego pozytywnie należy ocenić wprowadzenie przytoczonych zasad. Potrzeba rozstrzygania wątpliwości na rzecz strony (przedsiębiorcy) zauważona została wcześniej chociażby w orzecznictwie Trybunału Konstytucyjnego czy Naczelnego Sądu Administracyjnego, które niejednokrotnie wypowiadały się w tym temacie ${ }^{21}$. Zwracał na nią uwagę również Rzecznik Praw Obywatelskich ${ }^{22}$. Koresponduje ona ponadto z kodeksową zasadą pogłębiania zaufania obywateli do

władz administracyjnych, Warszawa 1948; M. Zimmermann, Pojęcie administracji publicznej a swobodne uznanie, Poznań 1959; M. Szewczyk, Nadzór w materialnym prawie administracyjnym, [w:] idem, Nadzór w materialnym prawie administracyjnym. Administracja wobec wolności i innych praw podmiotowych jednostki, Poznań 1995, s. 154-156; M. Mincer, Pojęcie niedookreślone w orzecznictwie NSA, „Nowe Prawo” 1984, nr 7-8; J. Starościak, [w:] System prawa administracyjnego, t. 3, red. T. Rabska, J. Łętowski, Wrocław-Warszawa-Kraków 1978, s. 76; M. Zdyb, Publiczne prawo gospodarcze, Kraków 1998, s. 110; Z. Janowicz, Kodeks postępowania administracyjnego. Komentarz, Warszawa 1999, s. 304. Szerzej na ten temat zob. I. Bogucka, Państwo prawne a problem uznania administracyjnego, „Państwo i Prawo” (dalej: PiP) 1992, nr 10, s. 32-43 i cytowana tam literatura; J. Jendrośka, Granice dyskrecjonalnych uprawnień administracji publicznej, [w:] Administracja publiczna u progu XXI wieku. Prace dedykowane prof. dr. hab. Janowi Szreniawskiemu z okazji Jubileuszu 45-lecia pracy naukowej, red. Z. Niewiadomski et al., Przemyśl 2000, s. 80-87; E. Ochendowski, Prawo administracyjne. Część ogólna, Toruń 2006, s. 203-214; M. Wierzbowski, [w:] M. Wierzbowski et al., Prawo administracyjne, Warszawa 2007, s. 269. Ze starszego piśmiennictwa zob. zwłaszcza: T. Bigo, Kontrola uznania administracyjnego, „Sprawozdania Wrocławskiego Towarzystwa Naukowego" 14a, 1959; W. Lang, A. Delorme, Z zagadnień tzw. swobodnego uznania, PiP 1957, nr 4-5, s. 729-751; K. Nowacki, Kontrola decyzji opartych na uznaniu administracyjnym, Wrocław 1979; M. Zdyb, Prawny interes jednostki w sferze prawa administracyjnego. Studium teoretyczno-prawne, Lublin 1991, s. 247 n. Zob. także orzeczenie NSA z dnia 23 września 1983 r., SA 1123/83, niepubl.; orzeczenie NSA z dnia 26 maja 1981 r., SA 974/81, ONSA 1981, poz. 49; wyrok NSA z dnia 27 września 1994 r., II SA 727/94, „Jurysta” 1995, nr 2, s. 19 n.; wyrok SN z dnia 24 czerwca 1993 r., III ARN 33/93, PiP 1994, nr 9, s. 111; wyrok NSA z dnia 19 marca 1981 r., SA 234/81, ONSA 1981, nr 1, poz. 23.

20 Por. art. 83 ustawy o swobodzie działalności gospodarczej i związane z wykładnią tego przepisu orzecznictwo sądowe (np. wyrok WSA w Kielcach, II SA/Ke 99/17, LEX nr 2289707; wyrok WSA w Łodzi, I SA/Ł 1163/14, LEX nr 1646686; wyrok WSA w Gliwicach, III SA/GL 329/14, LEX nr 1513667; wyrok NSA, II FSK 780/12, LEX nr 1495003; wyrok WSA w Lublinie, III SA/Lu 112/13, LEX nr 1326339).

21 Por. wyrok TK z dnia 18 lipca 2013 r. w sprawie SK 18/09, OTK ZU 2013, nr 6A, poz. 80; wyrok TK z dnia 15 lutego 2005 r., K 48/04, OTK-A 2005, nr 2, poz. 15; wyrok TK z dnia 21 kwietnia 2004 r., K 33/03, OTK 2004, nr 4, poz. 31; wyrok Trybunału Konstytucyjnego z dnia 7 lutego 2001 r., K 27/00, OTK 2001, nr 2, poz. 29; uchwała NSA z dnia 13 listopada 2012 r., II OPS 2/12, NSAiWSA 2013, nr 2, poz. 23; wyrok NSA z dnia 20 maja 2016 r., II FSK 1249/14, LEX nr 2082816; wyrok NSA z dnia 19 maja 2016 r., II FSK 902/14, LEX nr 2083021.

22 Zob. O zasadzie rozstrzygania wątpliwości na korzyść podatnika. Praktyczny poradnik, https://www.rpo.gov.pl/sites/default/files/Rozstrzyganie\%20na\%20korzy\%C5\%9B\%C4\%87\%20 podatnika $\% 20 \% 28$ in $\% 20$ dubio $\% 20$ pro\%20tribitario\%29\%20-\%20poradnik.pdf. W literaturze zob. A. Mariański, Rozstrzyganie wattpliwości na korzyść podatnika. Zasada prawa podatkowego, Warszawa 2011; M. Durczyńska, Rozstrzyganie watpliwości na korzyść podatnika (in dubio pro tributario), „Monitor Podatkowy” 12, 2015; B. Brzeziński, Rozstrzyganie watpliwości na korzyść podatnika jako 
organów państwa (art. 8 k.p.a.) czy zasadą przekonywania (art. 11 k.p.a.), a także art. 12 projektu ustawy Prawo przedsiębiorców, który nakłada na organy administracji gospodarczej obowiązek prowadzenia postępowań w sposób budzący zaufanie przedsiębiorców do władzy publicznej (powtórzenie art. 11 k.p.a.), kierując się zasadami proporcjonalności, bezstronności i równego traktowania. Ponadto w art. 22 Konstytucji RP można dopatrywać się konstytucyjnych źródeł tej zasady.

Pozytywnie należy ocenić także wprowadzenie do projektu ustawy Prawo przedsiębiorców zasady proporcjonalności. Dotychczas obowiązująca ustawa o swobodzie działalności gospodarczej nie wymieniała jej expressis verbis. Nie oznacza to oczywiście, że zasada ta nie obowiązywała. Wyprowadzano ją jednak z innych przepisów prawa, w tym z konstytucyjnej zasady demokratycznego państwa prawa, z art. 31 ust. 3 Konstytucji $\mathrm{RP}^{23}$ oraz orzecznictwa Trybunału Sprawiedliwości UE i Europejskiego Trybunału Praw Człowieka ${ }^{24}$.

Znaczenie tej zasady jest podkreślane do tego stopnia, że niektórzy autorzy słusznie wprost przyjmują ją za zasadę prawa publicznego ${ }^{25}$. Zgodnie z art. 31 ust. 3 Konstytucji RP ograniczenia w zakresie korzystania z konstytucyjnych wolności i praw mogą być ustanawiane jedynie w ustawie i tylko wtedy, gdy są konieczne w demokratycznym państwie dla jego bezpieczeństwa lub porządku publicznego bądź dla ochrony środowiska, zdrowia i moralności publicznej albo wolności i praw innych osób. Ograniczenia te nie mogą naruszać istoty wolności i praw. Jak się powszechnie przyjmuje, stanowi ona wyraz dążenia do racjonalizacji działania organów administracji publicznej ${ }^{26}$. Oznacza to, że każdy organ administracji publicznej, stosując prawo, a zwłaszcza określony środek nadzorczy, musi uwzględniać całokształt okoliczności danego wypadku, kierując się z jednej strony przesłankami zastosowania tego środka (kryteria nadzoru), z drugiej zaś — brać pod uwagę rodzaj naruszenia, zawinienie oraz cel, jaki chce osiągnąc ${ }^{27}$.

zasada wyktadni prawa podatkowego. Próba analizy, [w:] Ex iniuria non oritus ius. Księga pamiątkowa ku czci prof. W. Łączkowskiego, red. A. Gomułowicz, J. Małecki, Poznań 2003.

23 Także w art. 51 ust. 2 czy w art. 228 ust. 5 Konstytucji RP.

24 Por. S. Dudzik, Glosa do wyroku z 27 IX 1994, II SA 727/94, PiP 1995, nr 7, s. 10-116.

25 Por. C. Balasiński et al., [w:] Prawo gospodarcze. Zagadnienia administracyjnoprawne, red. H. Gronkiewicz-Waltz, M. Wierzbowski, Warszawa 2017, s. 91 n.; K. Strzyczkowski, Prawo gospodarcze publiczne, Warszawa 2011, s. $96 \mathrm{n}$.

26 Zob. A. Walaszek-Pyzioł, Zasada proporcjonalności w orzecznictwie Trybunału Konstytucyjnego, PUG 1995, nr 1; eadem, Wolność gospodarcza w ustawodawstwie gospodarczym Republiki Federalnej Niemiec, PUG 1994, nr 3; K. Wojtyczek, Granice ingerencji ustawodawczej w sferę praw człowieka w Konstytucji RP, Kraków 1999, s. 139 n.; D. Kijowski, Zasada adekwatności w prawie administracyjnym, PiP 1986, nr 6, s. 60.

27 Por. wyrok TK z dnia 1 marca 1994 r., U 7/93, OTK 1994, nr 1, poz. 5, zgodnie z którym przy stosowaniu kary administracyjnej organ administracyjny musi uwzględniać ,,subiektywny element zawinienia". Podobne stanowiska zajął NSA w orzeczeniu z dnia 27 marca 1991 r. (II SA 205/91, ONSA 3-4, poz. 92). Por. wyrok TK z dnia 14 czerwca 2004 r., SK 21/03, OTK 2004, nr 6, poz. 56; wyrok NSA z dnia 17 stycznia 1997 r., niepubl.; Glosa do wyroku NSA z 27 września 1994 r., PiP 1995, nr 7. 
Wykonywanie władzy publicznej wymaga zatem uwzględnienia wielu czynników, w tym tych dotyczących zarówno osoby, względem której mają być zastosowane, jak i dobra, które ma być chronione ${ }^{28}$. Zastosowany środek nie może być, $z$ jednej strony, nadmiernie dolegliwy, z drugiej zaś — nie może też być zbyt łagodny. Innymi słowy środki muszą być adekwatne do wykrytych nieprawidłowości; powinny być na tyle surowe, by podmiotowi, którego sprawa dotyczy, nie kalkulowało się powtarzanie naruszeń.

Wskazana w projekcie ustawy Prawo przedsiębiorców zasada odpowiedzialności funkcjonariuszy publicznych za naruszenie prawa (art. 13 projektu) nie wprowadza żadnej zmiany w stosunku do dotychczas obowiązującego stanu prawnego. W tym zakresie zastosowanie znajduje ustawa o odpowiedzialności majątkowej funkcjonariuszy publicznych za rażące naruszenie prawa ${ }^{29}$. Nie wyklucza to oczywiście możliwości dochodzenia roszczeń przez przedsiębiorcę od Skarbu Państwa, jednostek samorządu terytorialnego lub innych osób prawnych, które wykonują władzę publiczną z mocy prawa, na zasadach określonych w kodeksie cywilnym (art. 417 n. k.c.) ${ }^{30}$. W konsekwencji bez zmian pozostaje pierwszoplanowa odpowiedzialność Skarbu Państwa (jednostki samorządu terytorialnego lub osoby prawnej wykonującej władzę publiczną) za szkodę wyrządzoną przez niezgodne z prawem działanie lub zaniechanie przy wykonywaniu władzy publicznej (odpowiedzialność na zasadzie ryzyka) oraz w wypadku stwierdzenia takiej odpowiedzialności Skarbu Państwa (jednostki samorządu terytorialnego lub osoby prawnej wykonującej władzę publiczną) ewentualnej odpowiedzialności funkcjonariusza publicznego (odpowiedzialność na zasadzie winy - art. 5 ustawy o odpowiedzialności majątkowej funkcjonariuszy publicznych za rażące naru-

28 Zob. K. Kiczka, Niektóre problemy prawne nadzoru administracyjnego w obszarze dziatalności gospodarczej, [w:] Nadzór administracyjny. Od prewencji do weryfikacji, red. C. Kociński et al., Wrocław 2006, s. 182-183.

29 Ustawa z dnia 20 stycznia 2011 r. (tekst jedn. Dz.U. z 2016 r. poz. 1169).

30 Por. J. Kosik, Zasady odpowiedzialności państwa za szkody wyrządzone przez funkcjonariuszy, Wrocław 1961; A. Szpunar, Tendencje rozwojowe odpowiedzialności Skarbu Państwa, [w:] Studia z prawa zobowiazań, red. Z. Radwański, Warszawa-Poznań 1979; J. Kremis, Skutki prawne w zakresie odpowiedzialności odszkodowawczej państwa na tle wyroku Trybunału Konstytucyjnego, PiP 2002, nr 6, s. 40 n.; P. Granecki, Odpowiedzialność cywilna Skarbu Państwa za szkodę wyrzadzona dziataniem swojego funkcjonariusza (wybrane zagadnienia), „Palestra” 2000, nr 11-12, s. 6 n.; G. Bieniek, Odpowiedzialność Skarbu Państwa za szkody wyrzadzone przez funkcjonariuszy po wyroku Trybunału Konstytucyjnego z 4 grudnia 2001 r., „Przegląd Sądowy” 2002, nr 4, s. 3 n. Zasady tej odpowiedzialności ewaluowały publikacje: M. Safjan, Ewolucja odpowiedzialności władzy publicznej — od winy funkcjonariusza do bezprawności normatywnej, „Zeszyty Prawnicze UKSW” 3, 2003, nr 2, s. 143 n.; Z. Banaszczyk, [w:] Kodeks cywilny. Komentarz, t. 1, red. K. Pietrzykowski, Warszawa 2006, s. 1226 n.; W. Czachórski et al., Zobowiąania. Zarys wykładu, Warszawa 2007, s. 259-261; J. Gęsia, Od nieodpowiedzialności po bezprawność - ewolucja zasad odpowiedzialności odszkodowawczej Skarbu Państwa, [w:] Rozprawy prawnicze. Księga pamiątkowa Profesora Maksymiliana Pazdana, red. L. Ogiegła, W. Popiołek, M. Szpunar, Kraków 2005, s. 931-949. 
szenie prawa). Należy zauważyć, że choć projekt ustawy Prawo przedsiębiorców przewiduje odpowiedzialność funkcjonariuszy publicznych za naruszenie prawa, to zgodnie z przepisami regulującymi tę odpowiedzialność funkcjonariusze ci ponoszą osobistą majątkową odpowiedzialność tylko za rażące naruszenie prawa. Inne niż rażące naruszenie prawa może jednak skutkować odpowiedzialnością dyscyplinarną.

Wprowadzona art. 14 projektu ustawy Prawo przedsiębiorców zasada nazwana przez prawodawcę zasadą pewności prawa ${ }^{31}$ stanowi, że organ bez uzasadnionej przyczyny nie odstępuje od utrwalonej praktyki rozstrzygania spraw w takim samym stanie faktycznym i prawnym. Rozwiązanie to nawiązuje bezpośrednio do konstytucyjnej zasady pewności prawa ${ }^{32}$; jest też powtórzeniem art. $8 \S 2$ k.p.a. Przede wszystkim należy podkreślić, że zasada pewności prawa oznacza nie tylko pewien stały nurt wykładni przepisów prawa, lecz także względną petryfikację regulacji prawnych (zasada ostrożnej legislacji), w tym ewentualną przewidywalność ich zmian ${ }^{33}$. Nazwa zasady nieco odstaje więc od treści normy prawnej, jaką wyraża art. 14 projektu. Niemniej jednak pozytywnie należy ocenić starania prawodawcy zmierzające do eliminowania rozbieżności orzeczniczych w sprawach opartych na tym samym stanie faktycznym i prawnym. Przepis wymaga zatem od organu stosującego określoną normę prawną jej jednolitej interpretacji, a ewentualne odstępstwa wymagać będą rzetelnego wyjaśnienia w uzasadnieniu rozstrzygnięcia.

Do pewnego stopnia rozwinięciem określonej art. 14 projektu ustawy Prawo przedsiębiorców zasady pewności prawa są art. 33-35 projektu, które w znacznym stopniu powielają dotychczasową regulację ustawy o swobodzie działalności gospodarczej w zakresie prawa przedsiębiorcy do wydania wiążącej organ interpretacji prawa. W tym kontekście szczególnie ważnym uzupełnieniem zasady pewności prawa jest art. 35 ust. 3 projektu, który przewiduje związanie organu administracji publicznej tak zwaną utrwaloną praktyką interpretacyjną. Przedsiębiorca, który zastosuje się do takiej praktyki, nie może być obciążony sankcjami administracyjnymi, finansowymi lub karnymi w zakresie, w jakim działał zgodnie z utrwaloną praktyką interpretacyjną (art. 10a ust. 5 ustawy o swobodzie

31 Zob. s. 37 uzasadnienia do projektu ustawy Prawo przedsiębiorców.

32 Zob. orzeczenie TK z dnia 2 marca 1993 r., K 9/92, OTK 1993, nr 1, poz. 6; orzeczenie TK z dnia 24 maja 1994 r., K 1/94, OTK 1994, nr 1, poz. 10; wyrok TK z dnia 5 stycznia 1999 r., K 27/98, OTK 1999, nr 1, poz. 1.

33 Zob. S. Wronkowska, Zmiany w systemie prawnym, PiP 1991, z. 8; Z. Tabor, Teoretyczne problemy legalności, Katowice 1998, s. 65 n.; M. Chlipała, Zaufanie do administracji publicznej a normatywizacja przyrzeczenia administracyjnego, PPP 2017 r., nr 12, s. 47; W. Jakimowicz, Kilka uwag o niepewności w prawie administracyjnym, [w:] Pewność sytuacji prawnej jednostki w prawie administracyjnym, red. A. Błaś, Warszawa 2012, s. 216. 
działalności gospodarczej) ${ }^{34}$. Analogiczne rozwiązanie dotyczy tak zwanych objaśnień prawnych publikowanych w Biuletynie Informacji Publicznej (art. 33 w zw. $\mathrm{z}$ art. 35 ust. 5 projektu ustawy Prawo przedsiębiorców).

Ważnym nowym obowiązkiem organów administracji gospodarczej jest udzielanie przedsiębiorcom w zakresie właściwości organu informacji o warunkach podejmowania, prowadzenia oraz zakończenia działalności gospodarczej (art. 15 projektu ustawy Prawo przedsiębiorców). Dotychczas, o ile obowiązek taki nie wynikał z przepisów szczególnych, organu administracyjnego nie obciążał taki obowiązek. Przepis jest sformułowany ogólnie, nie wynika z niego jednak obowiązek udzielania porad prawnych, wyjaśniania wątpliwości czy pouczania przedsiębiorcy co do konkretnych zachowań, jakie powinien podjąć w okolicznościach danego przypadku. Jak się wydaje, informacja udzielona przez organ powinna mieć charakter neutralny, edukacyjny i dotyczyć sytuacji abstrakcyjnych.

Ostatni z przepisów ogólnych projektu ustawy Prawo przedsiębiorców przewiduje ustanowienie nowego rzecznika - Rzecznika Małych i Średnich Przedsiębiorców (art. 16). Podstawą prawną jego ustanowienia będzie jednak - o ile projekt ustawy wejdzie w życie - ustawa o Rzeczniku Małych i Średnich Przedsiębiorców. Ponieważ omówienie tej nowej instytucji prawnej znacznie wybiega poza ramy niniejszego opracowania, w tym miejscu warto jedynie podkreślić szczególne uprawnienia (art. 8 projektu ustawy o Rzeczniku Małych i Średnich Przedsiębiorców), które w połączeniu $\mathrm{z}$ budżetem przewidzianym na jej funkcjonowanie dają szanse realnego działania w interesie przedsiębiorców. Szkoda tylko, że nazwa rzecznika odnosi się wyłącznie do małych i średnich przedsiębiorców, choć uprawnienia de facto i de iure dotyczą wszystkich, również tych mikro i dużych.

Przepisy ogólne projektu ustawy Prawo przedsiębiorców zasadniczo nie wprowadzają nowych rozwiązań w stosunku do obowiązujących pod rządami ustawy o swobodzie działalności gospodarczej. Oprócz regulacji działalności nieewidencjonowanej, korekty definicji działalności gospodarczej, niezmieniającej jednak jej istoty, przepisy ogólne podkreślają podstawowe zasady prowadzenia działalności gospodarczej. Niestety zdecydowana większość z nich powtarza regulacje poprzednio obowiązującej w tym zakresie ustawy, a niektóre nawiązują bezpośrednio lub pośrednio do rozwiązań przyjętych w Konstytucji RP, kodeksie postępowania administracyjnego czy innych aktach prawych. Pozytywnie należy ocenić jednak dążenie prawodawcy do uporządkowania przedmiotu regulacji prawa przedsiębiorców, na co wskazuje systematyka projektu ustawy, a także podkreślenie jej rangi poprzez wprowadzenie preambuły.

34 Szerzej zob. K. Pokryszka, Wybrane uprawnienia i obowiazki przedsiębiorców w świetle przepisów ustawy o swobodzie działalności gospodarczej, [w:] R. Blicharz et al., Przedsiębiorca. Zagadnienia wybrane, Katowice 2017, s. 92-95; A. Żurawik, Pisemna interpretacja organu co do zakresu i sposobu zastosowania przepisów w kontekście zmian ustawowych, [w:] ibidem, s. 103-112. 


\title{
SOME REMARKS ON THE GENERAL PROVISIONS OF THE DRAFT ACT — ENTREPRENEURS' LAW
}

\author{
Summary
}

The so-called "Constitution for Business," covering four laws, introduces several new solutions in relation to the Act on the freedom of economic activity. They are visible, among others, in the general provisions of the act - Entrepreneurs' Law. New solutions include the so-called unrecorded economic activity related to small-scale operations by natural persons.

Keywords: Constitution for Business, Entrepreneurs' Law, economic activity, unrecorded economic activity

\section{BIBLIOGRAFIA}

Bieniek G., Odpowiedzialność Skarbu Państwa za szkody wyrządzone przez funkcjonariuszy po wyroku Trybunatu Konstytucyjnego z 4 grudnia 2001 r., „Przegląd Sądowy” 2002, nr 4.

Bigo T., Kontrola uznania administracyjnego, „Sprawozdania Wrocławskiego Towarzystwa Naukowego" 14a, 1959.

Blicharz R., Pawełczyk M., Przedsiębiorca, czyli kto?, „Przegląd Ustawodawstwa Gospodarczego” 2004, nr 3.

Bogucka I., Państwo prawne a problem uznania administracyjnego, „Państwo i Prawo” 1992, nr 10.

Brzeziński B., Rozstrzyganie watpliwości na korzyść podatnika jako zasada wyktadni prawa podatkowego. Próba analizy, [w:] Ex iniuria non oritus ius. Księga pamiątkowa ku czci prof. W. Łaczkowskiego, red. A. Gomułowicz, J. Małecki, Poznań 2003.

Chlipała M., Zaufanie do administracji publicznej a normatywizacja przyrzeczenia administracyjnego, „Przegląd Prawa Publicznego” 2017, nr 12.

Czachórski W. et al., Zobowiazania. Zarys wykładu, Warszawa 2007.

Dudzik S., Glosa do wyroku z 27 IX 1994, II SA 727/94, „Państwo i Prawo” 1995, nr 7.

Durczyńska M., Rozstrzyganie wątpliwości na korzyść podatnika (in dubio pro tributario), „Monitor Podatkowy" 12, 2015.

Gęsia J., Od nieodpowiedzialności po bezprawność - ewolucja zasad odpowiedzialności odszkodowawczej Skarbu Państwa, [w:] Rozprawy prawnicze. Księga pamiątkowa Profesora Maksymiliana Pazdana, red. L. Ogiegła, W. Popiołek, M. Szpunar, Kraków 2005.

Granecki P., Odpowiedzialność cywilna Skarbu Państwa za szkodę wyrzadzona działaniem swojego funkcjonariusza (wybrane zagadnienia), „Palestra” 2000, nr 11-12.

Jakimowicz W., Kilka uwag o niepewności w prawie administracyjnym, [w:] Pewność sytuacji prawnej jednostki w prawie administracyjnym, red. A. Błaś, Warszawa 2012.

Janowicz Z., Kodeks postępowania administracyjnego. Komentarz, Warszawa 1999.

Jaśkowska M., Uznanie administracyjne, Toruń 1983.

Jaśkowska M., Związanie decyzji administracyjnej ustawa, Toruń 1998.

Jendrośka J., Granice dyskrecjonalnych uprawnień administracji publicznej, [w:] Administracja publiczna u progu XXI wieku. Prace dedykowane prof. dr. hab. Janowi Szreniawskiemu z okazji Jubileuszu 45-lecia pracy naukowej, red. Z. Niewiadomski et al., Przemyśl 2000.

Kiczka K., Niektóre problemy prawne nadzoru administracyjnego w obszarze działalności gospodarczej, [w:] Nadzór administracyjny. Od prewencji do weryfikacji, red. C. Kociński, Wrocław 2006.

Przegląd Prawa i Administracji 114, 2018

(C) for this edition by CNS 
Kiczka K., Ograniczanie wolności działalności gospodarczej w orzecznictwie Trybunału Konstytucyjnego, [w:] Kryzys prawa administracyjnego?, t. 1. Jakość prawa administracyjnego, red. D.R. Kijowski, A. Miruć, A. Suławko-Karetko, Warszawa 2012.

Kijowski D., Zasada adekwatności w prawie administracyjnym, „Państwo i Prawo” 1986, nr 6.

Kodeks cywilny. Komentarz. t. 1, red. K. Pietrzykowski, Warszawa 2006.

Konstytucja Rzeczypospolitej Polskiej, t. 1, red. L. Garlicki, M. Zubik, Warszawa 2016.

Konstytucja Rzeczypospolitej Polskiej. Komentarz, red. M. Haczkowska, Warszawa 2014.

Kosik J., Zasady odpowiedzialności państwa za szkody wyrządzone przez funkcjonariuszy, Wrocław 1961.

Kremis J., Skutki prawne w zakresie odpowiedzialności odszkodowawczej państwa na tle wyroku Trybunału Konstytucyjnego, „Państwo i Prawo” 2002, nr 6.

Lang W., Delorme A., Z zagadnień tzw. swobodnego uznania, „Państwo i Prawo” 1957, nr 4-5.

Łaszczyca G., Martysz C., Matan A., Kodeks postępowania administracyjnego. Komentarz, t. 1. Komentarz do art. 1-103, Warszawa 2010.

Łętowski J., Glosa do wyroku NSA z dnia 11 czerwca 1981 r., SA 820/81, OSPiKA 1982, z. 1-2, poz. 22.

Mariański A., Rozstrzyganie wątpliwości na korzyść podatnika. Zasada prawa podatkowego, Warszawa 2011.

Mincer M., Pojęcie niedookreślone w orzecznictwie NSA, „Nowe Prawo” 1984, nr 7-8.

Mincer M., Uznanie administracyjne, Toruń 1983.

Nowacki K., Kontrola decyzji opartych na uznaniu administracyjnym, Wrocław 1979.

Ochendowski E., Prawo administracyjne. Część ogólna, Torun 2006.

Pokryszka K., Wybrane uprawnienia i obowiąki przedsiębiorców w świetle przepisów ustawy o swobodzie działalności gospodarczej, [w:] Przedsiębiorca. Zagadnienia wybrane, red. R. Blicharz, Katowice 2017.

Prawo gospodarcze. Zagadnienia administracyjnoprawne, red. H. Gronkiewicz-Waltz, M. Wierzbowski, Warszawa 2017.

Safjan M., Ewolucja odpowiedzialności władzy publicznej — od winy funkcjonariusza do bezprawności normatywnej, „Zeszyty Prawnicze UKSW” 3, 2003, nr 2.

Starościak J., Swobodne uznanie w teorii prawa administracyjnego, Warszawa 1948.

Starościak J., Swobodne uznanie władz administracyjnych, Warszawa 1948.

Strzyczkowski K., Prawo gospodarcze publiczne, Warszawa 2011.

System prawa administracyjnego, t. 3, red. T. Rabska, J. Łętowski, Wrocław-Warszawa-Kraków 1978.

Szewczyk M., Nadzór w materialnym prawie administracyjnym, [w:] idem, Nadzór w materialnym prawie administracyjnym. Administracja wobec wolności i innych praw podmiotowych jednostki, Poznań 1995.

Szpunar A., Tendencje rozwojowe odpowiedzialności Skarbu Państwa, [w:] Studia z prawa zobowiązań, red. Z. Radwański, Warszawa-Poznań 1979.

Tobor Z., Teoretyczne problemy legalności, Katowice 1998.

Walaszek-Pyzioł A., Wolność gospodarcza w ustawodawstwie gospodarczym Republiki Federalnej Niemiec, „Przegląd Ustawodawstwa Gospodarczego” 1994, nr 3.

Walaszek-Pyzioł A., Zasada proporcjonalności w orzecznictwie Trybunału Konstytucyjnego, „Przegląd Ustawodawstwa Gospodarczego" 1995, nr 1.

Wierzbowski M. et al., Prawo administracyjne, Warszawa 2007.

Wojtyczek K., Granice ingerencji ustawodawczej w sfere praw człowieka w Konstytucji RP, Kraków 1999.

Wronkowska S., Zmiany w systemie prawnym, „Państwo i Prawo” 1991, nr 8.

Zdyb M., Prawny interes jednostki w sferze prawa administracyjnego. Studium teoretyczno-prawne, Lublin 1991. 
Zdyb M., Publiczne prawo gospodarcze, Kraków 1998.

Zimmermann M., Pojęcie administracji publicznej a swobodne uznanie, Poznań 1959.

Żurawik A., Pisemna interpretacja organu co do zakresu i sposobu zastosowania przepisów w kontekście zmian ustawowych, [w:] Przedsiębiorca. Zagadnienia wybrane, red. R. Blicharz, Katowice 2017. 